\title{
Landscape approach to formation of system of ecologically balanced use of natural resources: legal framework
}

\author{
Volodymyr Yermolenko ${ }^{1}$, Olena Hafurova ${ }^{1}$, Maryna Deineha ${ }^{1,}{ }^{*}$, Tamara Novak $^{1}$, Julia Sinitsky $^{2}$, and Umidjon Ulugov $^{3}$ \\ ${ }^{1}$ National University of Life and Environmental Sciences of Ukraine, 15 Heroiv Oborony Str., Kyiv, 03041, Ukraine \\ ${ }^{2}$ John Jay College of Criminal Justice, 524 West 59th Str., New York, NY 10019, United States of America \\ ${ }^{3}$ Youth of the 21st Century, 23A A. Sino Str., Gissar, Tajikistan
}

\begin{abstract}
The article is devoted to the analysis of legal framework and theoretical provisions of the landscape approach to the formation of the system of ecologically balanced use of natural resources, the definition of its essence and content, highlighting of conditions and principles of its functioning. Proposals for elimination of legal problems in the field of development and realization of the concept of ecologically balanced use of natural resources are covered. It is determined that the legal formulation of landscape approach principle to the use of natural resources will ensure unity, integrity, comprehensiveness of nature management, coherence and balance of interests in this area, implementation of ideas for the formation of system of environmentally sustainable use of natural resources and sustainable development concept, and the adoption of relevant regulations will solve our state's urgent task on the path to further European integration.
\end{abstract}

\section{Introduction}

The priority of further development of civilization is the harmonization of interactions of society and nature. However, the ecological situation continues to deteriorate relentlessly thus posing a real threat to the existence of mankind. And unrestrained pursuit of economic growth is leading to the destruction of natural resources potential. Intensive development of scientific and technological progress has led to a number of global environmental problems, each of which can threaten the destruction of our civilization.

Simultaneous resolution of environmental protection and socio-economic development issues is one of the main activities of any civilized state nowadays. Today there is a dilemma - how to combine the interests of nature conservation with the interests of economic development and social sphere, how to ensure systematic consideration of environmental and economic interests, which is a condition for sustainable (well-balanced) development as a new paradigm of interaction between society and nature (Fig. 1). It is necessary to solve a difficult task - to find a balance in the system «environment - economic development».

There is a need to develop and implement the concept of environmentally sustainable use of natural resources which should be based on reaching a compromise between economic, environmental and social needs of society and on the principles of sustainability. For this purpose, the need to develop the legal framework of landscape principle in nature management, which involves changing approaches to the use of natural resources taking into account negative consequences of human intervention in natural processes and the balance of interests of nature and society development, acquires special urgency.

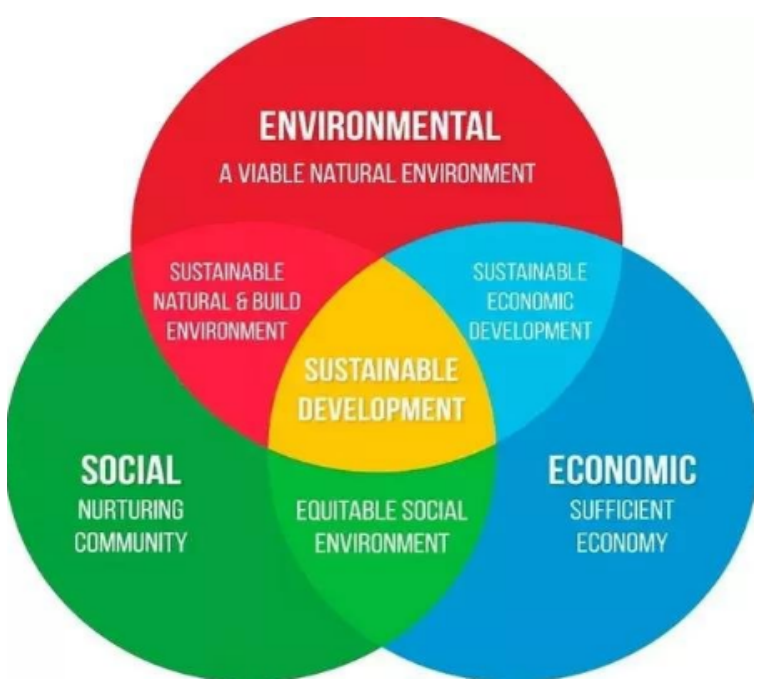

Fig. 1. Sustainable development [1].

The formation of the system of ecologically balanced use of natural resources is the subject of research by the following nature and economics scientists. Legal aspects of environmentally sustainable use of natural resources concept remain a little-researched problem. Specific proposals and projects of models of legal mediation of landscapes as a component of environment, as a source of satisfaction of ecological interests of humans and society as a whole were substantiated in scientific works.

The purpose of the article is to analyse the legal framework and theoretical provisions of the landscape approach to the formation of the system of ecologically

\footnotetext{
* Corresponding author: marinad@meta.ua
} 
balanced use of natural resources, the definition of its essence and content, identification of conditions and principles of its functioning.

\section{Results}

In 2015, the UN Summit on The issue of environmentally sustainable use of natural resources was first addressed at the World Summits on Environment and Development: in Rio de Janeiro in 1992 and Johannesburg in 2002. However, a breakthrough at the civilization level has not been achieved. Therefore, the XXI century should become a bifurcation point in the system «society nature» that should be accompanied by specific human actions to harmonize the relationship between society and nature.

In 2015, the UN Summit on Sustainable Development adopted «Sustainable Development Goals» (hereinafter SDG) - key areas of countries development for the period up to 2030 with 17 Global goals and 169 targets relevant to them (Fig. 2). Among the Global goals are: «Sustainable consumption and production patterns» (goal 12) aimed at reducing the impact on the environment by changes in production patterns and consumption of natural resources; «Conservation of marine resources») (goal 14) which involves conservation and sustainable use of oceans, seas and marine resources in the interests of sustainable development; "Protection and restoration of terrestrial ecosystems» (goal 15) aimed at promoting their rational use, rational forest management, combating desertification, stopping and reversing the process of land degradation and halting biodiversity loss, and others.

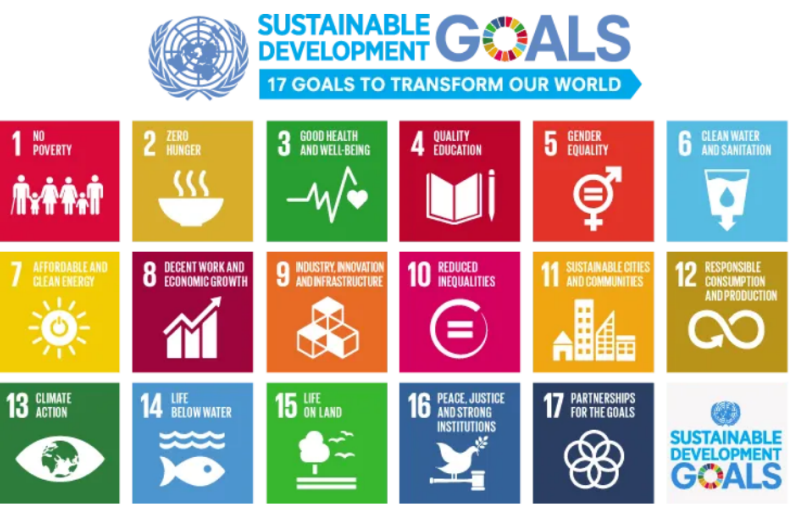

Fig. 2. Sustainable Development Goals [2].

Ukraine, like other UN member states, joined the global process of sustainable development. At the initiative of the Cabinet of Ministers of Ukraine and with the assistance of the UN system in Ukraine, an open and inclusive process of adaptation of the SDGs continued for a year. In 2017, the Cabinet of Ministers of Ukraine presented the National Report «Sustainable Development Goals: Ukraine» which defines basic indicators for achieving the SDG. The report presents the results of the adaptation of 17 global SDGs ( 86 tasks and 172 indicators of national development by 2030) taking into account the specifics of national development. Among the tasks envisaged by the National Report, the need to reduce the resource intensity of the economy, reduce the volume of waste generation and increase the volume of their processing and recycling based on innovative technologies and industries is identified under the Goal 12 «Sustainable consumption and production patterns».

However, the economic growth that everyone in the country aspires to and which is expected by the society will inevitably lead to an increase in natural resources use and consumption waste which in its turn will increase the anthropogenic burden on the environment. The understanding of the importance of responsible consumption and production implementation is present in the country but a balanced settlement of these issues requires a balanced and long-term political and economic effort focused on both production and consumption. According to the National Report, the National Policy should be based on 10 Year Framework of Programmes on Sustainable Consumption and Production Patterns (Rio, 2012), which is a global platform for capacity building and partnership in sustainable production and consumption.

The Law of Ukraine «On the Basic Principles (Strategy) of State Environmental Policy of Ukraine for the Period up to 2030» of 28.02.2019 defines as one of the main tasks the creation ecologically balanced system of natural resources use. The draft Strategy for Sustainable Development of Ukraine until 2030 envisages achieving a balanced and efficient use of natural resources and reducing the resource intensity of GDP by $40 \%$. At the same time, the formation of the system of ecologically balanced use of natural resources is possible, first of all, in case the provisions of the concept are implemented in strategic and programme documents.

In this regard, there appears a need for a scientific study of the essence and content of the system of ecologically balanced use of natural resources, defining the conditions and identifying the basic principles on which this system should be based (Fig. 3).

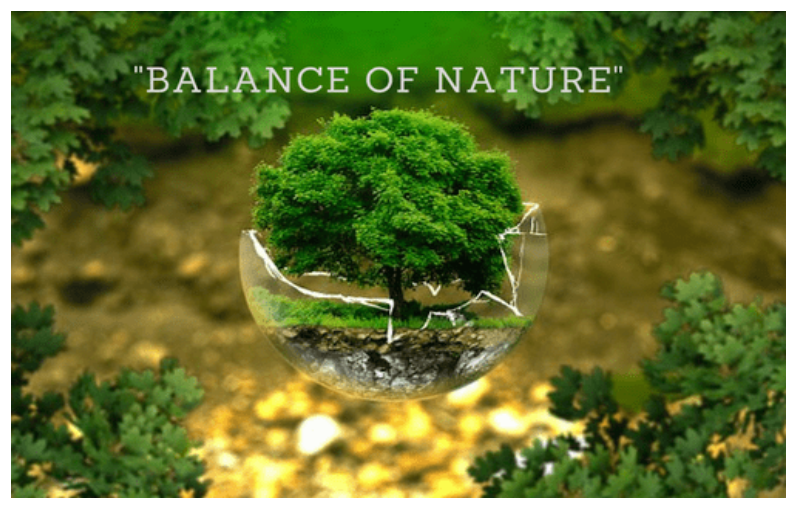

Fig. 3. Balance of nature [3].

In 1972, Secretary General of the Stockholm Conference M. Strong, covering the essence of the concept of ecological development, for the first time at the official level made a demand for the balance of use of natural resources, the possibility of economic growth within acceptable ecological and economic balance, when society controls the regulatory balance «between total anthropogenic impacts on the natural environment with its 
self-renewable capacity, with its endurance in relation to these impacts» [4, p. 95].

The scientific definition of ecologically balanced use of natural resources was first covered in the works of economist P.G. Oldak. The scholar described the equilibrium (balanced) use of natural resources as the one in which «society controls all aspects of its development, ensuring that the total anthropogenic load on the environment does not exceed the self-renewable capacity of natural systems» [5, p. 24].

M.M. Prykhodko researches the problems ofthe formation of the system of ecologically balanced use of natural resources (resource use). The scientist notes that ecologically balanced use of natural resources is an equilibrium ratio between the use of renewable natural resources and the intensity of their restoration, as well as the economical use of non-renewable natural resources $[6$, p. 93]. In the context of ecologically balanced use of natural resources it is very important to comply with the regulatory balance between the available amount of natural resources (resource potential) and the amount allowed for use, which is determined by the ecological potential of ecosystems, their self-renewable capacity [6, p. 94] Thus, ecologically balanced use of natural resources should be based on economic activity in the cycle «extraction of natural resources - resource-saving production with low resource intensity - economical use - expanded reproduction - waste disposal».

In this regard, ecologically balanced use of natural resources should meet the following conditions: use of natural resources with minimal labour costs, with simultaneous contribution of funds for their renewal and taking protection measures; full use of natural resources (without losses during extraction, transportation, processing); renewal of natural ecosystem from which a natural resource is extracted; use of renewable natural resources only in the amount of their annual growth; use of non-renewable natural resources only to meet the most urgent needs; waste-free production.

The related scientific literature also distinguishes the principles on which ecologically balanced use of natural resources should be based: the principle of systematic approach to the use of natural resources; the principle of consideration of natural conditions and resources zonality; the principle of integrated management of natural resources; the principle of conservation, restoration and reproduction of naturalness and biodiversity; the principle of inexhaustibility (annual use of renewable natural resources should not exceed $10 \%$ of their total amount); the principle of waste minimization (introduction of low-waste production, use of recyclables, waste disposal); the principle of observance of laws, rules and principles of natural resources use [6, p. 95].

Introduction of ecologically balanced system of nature management is directly related to the application of landscape approach to the use of natural resources. According to scientists, the landscape approach to the use of natural resources contributes to the restoration of ecosystems, mitigation and adaptation to climate change [7, p. 203], and can bring positive social benefits (e.g. employment or the return of valued wild species) and potentially contribute to improvements in human health and wellbeing [8, p. 21].

Legal codification of the principle of landscape approach to nature management is stipulated by PanEuropean Biological and Landscape Diversity Strategy (1995), according to which the countries of European Community took responsibilities to significantly reduce the threat to biological and landscape diversity in Europe, of which Ukraine is a part. The strategy was proposed by the Maastricht Declaration «Conserving Europe's Natural Heritage» (1993), which was based on the European Nature Protection Strategy (1990), the results of Dobris and Lucerne Environment Ministers Conferences (1991 and 1993) and the UN Conference on Environment and Development (1992), etc.

In 2000 , to ensure the sustainable development based on balanced and harmonious relationship between social needs, economic activity and the environment, the European Landscape Convention of 20.10.2000 was adopted, ratified by the Law of Ukraine of 07.09.2005. Pursuant to Article 1 of the Convention, «landscape» is defined as an area, as perceived by people, whose character is the result of the action and interaction of natural and/or human factors.

According to the Convention, Ukraine is obliged to: 1) to recognise landscapes in law as an essential component of people's surroundings, an expression of the diversity of their shared cultural and natural heritage, and a foundation of their identity; 2) to establish and implement landscape policies aimed at landscape protection, management and planning through the adoption of the specific measures; 3 ) to establish procedures for the participation of the general public, local and regional authorities, and other parties with an interest in the definition and implementation of the landscape policies; 4) to integrate landscape into its regional and town planning policies and in its cultural, environmental, agricultural, social and economic policies, as well as in any other policies with possible direct or indirect impact on the landscape.

As a party to the European Landscape Convention and other international agreements, Ukraine has committed itself to implementing landscape policy into national law. However, currently, the landscape as an object of legal regulation in the legislation of Ukraine is defined only in the Laws of Ukraine «On Environmental Protection» of 25.06.1991, «On Approval of National Programme of Formation of National Ecological Network of Ukraine for 2000-2015» of 21.09.2000, «On Ecological Network of Ukraine» of 24.06.2004 which contain general norms related to legislative provision of use and protection of landscapes.

The concept of a landscape approach to nature management, the recognition of the landscape as an object of legal regulation and the need to protect it began to develop in the scientific literature in Soviet times. In 1983, the first attempt was made to disclose the legal meaning of the «landscape». I.A. Brinke, exploring the essence of the legal regime of landscapes, described the landscape as a set of legally defined areas of land or water consisting of interacting natural or natural and anthropogenic components characterized by typicality or beauty, which 
are protected by the state in the interests of science, education, culture and recreation [9, p. 9].

Landscape relations are the subject of research of many foreign scientists. Thus, in particular, N. Ockendon characterizes landscapes as large, heterogeneous and multifunctional environments that provide diverse services and values to multiple stakeholders [7, p. 199]. $\mathrm{Ch}$. Albert defines the landscape as the result of the action and integration of natural and/or human factors $[10, \mathrm{p}$. $15]$.

In national science of environmental and land law, the problem of recognizing the landscape as an object of legal regulation is just beginning to be discussed. In scientific works, the term «landscape» is explained from different points of view. V.I. Andreitsev, V.V. Nosik, M.V. Shulga define the concept of «landscape» by describing the legal significance of land as a national value, the object of property rights of Ukrainian people, the most important part of environment. So V.I. Andreitsev considers landscapes as complex objects of legislation, points out that national land value is the immensity of its properties for meeting physical, spiritual, aesthetic, cognitive, health and medical, recreational, historical, cultural and other needs, formation of natural and natural-anthropogenic landscapes [11, p. 15].

At the same time, as noted by S.V. Yelkin, the mentioned views of the above scholars on the definition of the landscape as a whole do not reveal its legal features. In legal sense, the concept of «landscape» is physical and legal features of the landscape set out in the law, as well as the competence of a subject of law on the landscape, where physical features are objective factors that will directly affect the definition of the specifics of the legal regime of the landscape, the absence of which does not allow to formulate the definition of the landscape as a legal category $[12$, p. 11]. S.V. Yelkin characterizes the landscape as a territory with a set of natural and artificial components, which form a single whole and are in the optimal quantitative ratio as defined by law, where land acts as a spatial basis [12, p. 14].

Comparative analysis of legal regulation of landscape protection in Ukraine and the European Union was carried out by O.V. Lozo who characterized the landscape as a territorial complex with a specific location recognized by existing legislation and law, within which natural and/or anthropogenic components are in constant interaction and adaptation to each other and constitute a united system $[13$, p. 7]. The scientist recognizes natural resources (land, water, flora, fauna, subsoil, air, etc.) as natural components of the landscape to the extent they affect it; buildings, transport routes, other man-made objects - as anthropogenic ones [13, p. 9].

Thus, the landscape as an object of legal regulation is a holistic natural or natural-anthropogenic system, which is characterized by relative homogeneity of interacting structural elements.

It should be noted that nowadays landscape planning is actively spreading as one of the ecologically oriented means of nature management in most developed countries of the world (Fig. 4). For example, the Wicken Vision in the Cambridgeshire fens, Cairngorms Connect project in the Scottish Highlands, Wild Ennerdale [7, p. 206]. In our country, only the first steps are being taken to introduce landscape planning into the policy of territorial development. In the future this will help to strengthen the relationship between environmental requirements in the field of nature management and economic, social and cultural interests of people, encouraging them to adhere to the sustainable development goals.

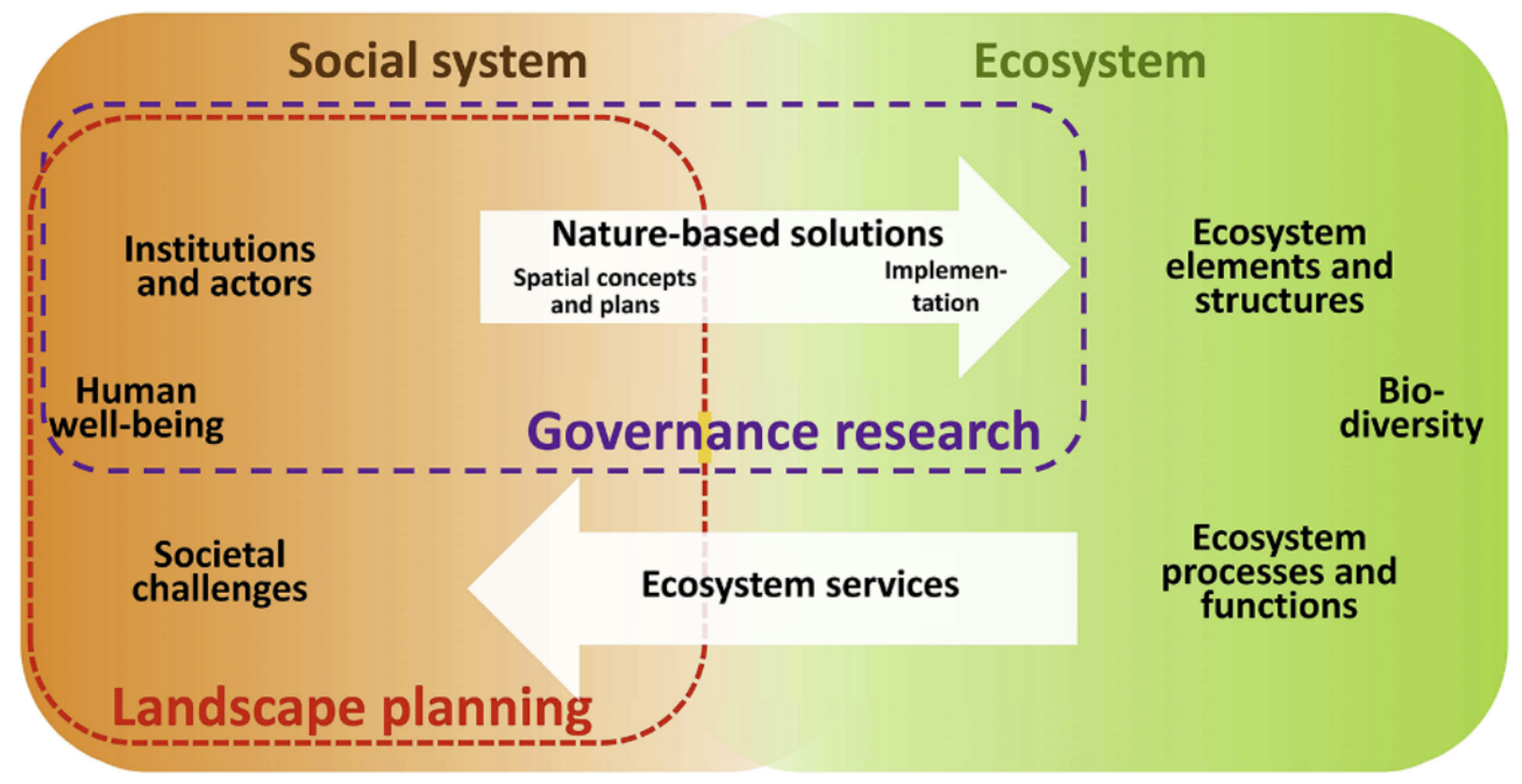

Fig. 4. Landscape planning [14].

Indeed, the need to implement the principles and approaches of modern landscape planning (especially in its European sense) into the practice of national natural resource planning is a close relationship of landscape 
planning with the concept of sustainable development, which Ukraine adheres to. Landscape planning is a strong forward-looking action to design, enhance or restore landscapes that serves at the interface between science and practice $[10$, p. 13]. According to the draft Law of Ukraine «On Landscapes», landscape planning itself is designed to ensure sustainable nature management. Besides, the spatial planning procedure in Ukraine is characterized by the dominance of town-planning approach, a strict focus on general schemes and the subordinate role of environmental requirements. This imbalance will help to correct the implementation of the principles of landscape planning.

According to the draft Law of Ukraine «On Landscapes», landscape planning is the development of a project for use of landscapes or a project to change the goals and methods of their management using a set of methodological tools used to build such a spatial organization of society activities in specific landscapes, which ensures sustainable nature management and preservation of basic functions of these landscapes as a life support system. As it is seen from this definition, landscape planning is becoming one of the primary tools for ensuring sustainable development in Ukraine.

Landscape planning has a potential to suggest land use options to achieve environmental objectives, to explore the respective impacts, and to provide recommendations for implementation in practice [15, p. 152]. One aim of landscape planning is to craft comprehensive and spatial strategies for developing multifunctional landscapes that minimize societal challenges and provide diverse ecosystem services to different groups of people [10, $\mathrm{p}$. $16]$.

Taking into account that landscape planning ensures the implementation of the basic directions of sustainable development policy, it is deemed necessary to form and implement landscape policy in Ukraine, develop legislation, as well as intensify research in the field of landscape planning and its practical use.

Research and analysis of scientific approaches to the outlined sphere of public relations allowed to define the principle of the landscape approach in nature management as an ecologically oriented system of means of planning, designing and organization of landscapes used for construction of such spatial organization of nature management that will provide sustainable and complex use and reproduction of natural resources, preservation of their main functions as a source for meeting material and spiritual needs of humans and the society. This principle has not yet become widespread in the field of natural resources legal relations, only the first steps are taken to enact it in the norms of natural resources legislation. At the same time, the Constitution of Ukraine emphasizes that the most important environmental relations, in particular, the principles of using natural or partially altered landscapes, should be regulated exclusively by laws.

On 14.06.2011, the Verkhovna Rada of Ukraine approved in principle the draft Law of Ukraine «On Landscapes» aimed at ensuring protection, regulation and planning of landscapes. According to the draft Law, a landscape is defined as an integral comprehensive natural- territorial (geographical) complex which is the result of action and interaction of natural and/or anthropogenic factors and consists of interacting natural or natural and anthropogenic components and complexes of lower taxonomy rank. The draft Law formulated the goals and principles of legal regulation of landscape planning and protection, legal aspects of state regulation, the system of legal measures in the field of landscape protection, etc. However, on 15.03.2012 the draft Law of Ukraine «On Landscapes») was rejected as inconsistent with the Constitution of Ukraine, legislation framework in the field of environmental protection, as the one that does not provide for comprehensive settlement of the outlined issues and does not introduce fundamentally new approaches to landscape protection.

Indeed, the legalization of the principle of a landscape approach to the use of natural resources will ensure the unity, integrity, comprehensiveness of nature management, coherence and balance of interests in this area, implementation of ideas for an ecologically balanced system of natural resources and the sustainable development concept put forward at the UN conference in Rio de Janeiro in the "Agenda for the XXI century» (1992), and the adoption of relevant regulations is a necessary step towards solving the urgent task of our state on the path to further European integration.

\section{Conclusions}

At the beginning of the XXI century, Ukraine still ranks first in the world in terms of consumption of natural resources per GDP unit and has the highest rate of industrial waste per capita. As a result, our country has an extremely degraded natural resource potential. And the mechanisms for regulating the natural foundations of life are not effective and efficient. As a result, natural foundations of socio-economic development are undermined, ecological conditions of human life and their health are rapidly deteriorating. At the same time, Ukraine's natural resource potential is estimated as one of the largest on the planet. It is determined that under conditions of efficient use, Ukrainian lands are able to feed 6 times more people than we have today. However, occupying only $6 \%$ of Europe, Ukraine has $35 \%$ of its diversity [16, p. 9].

Therefore, the most important task is to optimally and rationally use this potential in the interests of well-being of present and future generations. We are talking about the possibility of balanced environmental development of Ukraine based on an innovative model of economic development. It should include the latest achievements of science, modern knowledge-intensive high-tech industries, advanced energy and resource-saving technologies and provide for the application of environmentally sound principles of development.

It is time to form a system of nature management, ensuring its strategic orientation on sustainable development principles. The main strategic direction of Ukraine's development should be the ecological restructuring of its economy and the priority elimination of excessive technogenic pressures on the environment. 
Ecologically balanced use of natural resources is a decisive factor in preserving the life and health of every human, ensuring the national security of the country.

\section{References}

1. N. Ademovic, Sustainable development and concrete bridges, in XVII anniversary international scientific conference by construction and architecture, Sofia, Bulgaria, October 2018. https://www.researchgate.net/publication/32921825 9. Accessed 21 Dec 2020.

2. The Sustainable Development Goals. https://www.un.org/sustainabledevelopment/blog/20 15/12/sustainable-development-goals-kick-off-withstart-of-new-year/. Accessed 21 Dec 2020.

3. Balance of nature. https://www.brightassignment.com/blogview.php/About-Balance-of-Nature-and-Definitionof-Balance-of-Nature. Accessed 22 Dec 2020.

4. M.S. Kubarev, M.N. Ignatieva, Eco-friendly nature management is one of the main conditions for sustainable development. Bulletin of the Ural State Mining University. Economic sciences 1(49), 94-100 (2018).

5. P.G. Oldak, Equilibrium nature management. An economist's view (Nauka, Novosibirsk, 1983), p. 128.

6. M.M. Prikhodko, M.M. Prikhodko (senior), N.F. Prikhodko, L.S. Kosilo, Balanced resource use (theoretical aspect). Ecological safety and balanced resource use: scientific and technical journal 2(6), 92-96 (2012).

7. N. Ockendon et al., One hundred priority questions for landscape restoration in Europe. Biological Conservation. 221, 198-208. (2018).

8. T.B. Aronson et al., Restoring ecosystem health to improve human health and well-being: physicians and restoration ecologists unite in a common cause. Ecol. Soc., 39 (2016).

9. Y.A. Brynke, Legal protection of the landscape in the Latvian SSR (Moskva, 1984), p. 19.

10. Ch. Albert et al., Addressing societal challenges through nature-based solutions: How can landscape planning and governance research contribute? Landscape and Urban Planning. 182, 12-21 (2019).

11. V.I. Andreitsev, Environmental law of Ukraine: problems of integration and differentiation. Problems of integration and differentiation in environmental law (NHU, Dnipropetrovsk, 2014), pp. 5-33.

12. S.V. Yelkin, Legal regulation of landscape use and land protection in Ukraine (Kyiv, 2012), p. 20.

13. O.V. Lozo, Legal regulation of landscape protection in Ukraine and the European Union (Kharkiv, 2015), p. 22.

14. C. Albert, B. Schröter, D. Haase, M. Brillinger, J. Henzeet al., Addressing societal challenges through nature-based solutions: How can landscape planning and governance research contribute? Landscape and Urban Planning. 182, 12-21 (2019). doi: 10.1016/j.landurbplan.2018.10.003.

15. C. von Haaren, C. Albert. Integrating ecosystem services and environmental planning: Limitations and synergies. International Journal of Biodiversity Science, Ecosystem Services \& Management. 7(3), 150-167 (2011). https://doi.org/10.1080/ 21513732.2011.616534.

16. O.M. Kovalenko, Ecological aspects of balanced development of Ukraine. Ecology: Eastern European Journal of Advanced Technologies. 2/11(62), 7-11 (2013). 